\title{
ANALISIS FAKTOR PENDORONG DAN PENARIK WISATAWAN UNTUK BERBELANJA DI FACTORY OUTLET KOTA BANDUNG
}

\author{
Irwan Haribudiman \\ Program Magister Kajian Pariwisata, \\ Sekolah Pascasarjana - Universitas Gadjah Mada
}

\begin{abstract}
This research was intended to analyze of tourists' push and pull factors to shop in factory outlet at Bandung. Moreover, the objectives of this research are:

(1) to analyze the profile and perception of domestic tourists toward push and pull factors; (2) to know the influences of these drives on the tourists' visiting frequency; and (3) to count the contribution of each factor toward the frequency of tourists' visit to the factory outlets each year at Bandung.

The research used descriptive analytical method and the data were collected through surveys and questionnaires. The data includes an overview of research area, tourists' profiles, and tourists' perceptions about the push and pull factors to shop in factory outlet at Bandung. This research put 97 respondents, and the technique used in this research was accidental sampling.

The results of the research could be explained as below. First, the tourists' profiles based on actual market conditions could be divided into groups as psycho centrist, repeaters, active shoppers, and the price shoppers. Besides, the origin of majority tourists were coming from Jakarta and its surrounding areas who have a fixed job, middle income, and a lifestyle that tends to be wasteful and luxurious. Second, the drive that most influence the tourists to shop is the motive to strengthen family's bound or friendship. Meanwhile, the variations of good that sold at factory outlets is the main pull factor to travel to these destinations. Third, through the data, it analysis shown that both of two factors were carried out a positive and significant influence toward the frequency of tourists' visit each year, by giving contribution of $18 \%$ for the push factors, and $19 \%$ for the pull factor. Furthermore, when both of two factors were combined, it could provide a greater contribution value about $26.5 \%$, and the remains of $73.5 \%$ is epsilon that were explained by other variables which are not examined in this study.
\end{abstract}

\section{Keywords:}

tourist profiles, shopping tourism, push and pull factors.

\section{INTISARI}

Penelitian ini dilakukan dalam rangka menganalisis faktor pendorong dan penarik wisatawan untuk berbelanja di factory outlet Kota Bandung. Tujuan yang hendak dicapai meliputi: pertama, mengetahui profil dan persepsi wisatawan domestik mengenai faktor pendorong dan penarik. Kedua, mengolah hasil yang didapatkan dari kedua faktor tersebut untuk melihat pengaruhnya terhadap frekuensi kunjungan wisatawan. Ketiga, 
melihat kontribusi masing-masing faktor terhadap frekuensi kunjungan ke factory outlet Kota Bandung setiap tahunnya.

Metode penelitian yang digunakan adalah deskriptif analitis dari data yang dikumpulkan melalui survai dan kuesioner. Data yang dimaksud meliputi, gambaran umum daerah penelitian, profil wisatawan, dan persepsi mereka mengenai faktor pendorong dan penarik untuk berbelanja di factory outlet Kota Bandung. Pengambilan sampel sendiri menggunakan metode accidental sampling dengan responden sebanyak 97 orang.

Hasil penelitian ini adalah: pertama, berdasarkan kondisi aktual pasar yang berbelanja ke factory outlet Kota Bandung profil wisatawan dapat dikelompokkan menjadi, psikosentris, repeater, actives shopper, dan price shopper. Selain itu, mayoritas wisatawan berasal dari Kota Jakarta dan sekitarnya yang bekerja tetap, berpenghasilan menengah, tetapi memiliki gaya hidup cenderung boros dan mewah. Kedua, faktor pendorong wisatawan yang paling mempengaruhi untuk berbelanja adalah motif mempererat hubungan dengan keluarga atau teman. Sedangkan dari faktor penarik, variasi barang yang dijual merupakan alasan utama untuk berwisata ke destinasi ini. Ketiga, melalui hasil pengolahan data yang dilakukan ternyata kedua faktor tersebut memberikan pengaruh positif dan signifikan terhadap frekuensi kunjungan wisatawan setiap tahunnya, dengan kontribusi sebesar $18 \%$ untuk faktor pendorong, dan $19 \%$ untuk faktor penarik. Tetapi sebenarnya bila kedua faktor tersebut digabungkan, mampu memberikan nilai kontribusi yang lebih besar yakni $26,5 \%$, dan sisanya $73,5 \%$ dijelaskan oleh variabel lain yang tidak diteliti dalam penelitian ini.

\section{Kata Kunci:}

profil wisatawan, wisata belanja, faktor pendorong dan penarik,

\section{PENDAHULUAN}

Dalam perkembangan industri pariwisata telah merambah berbagai hal yang sering digunakan sebagai dayatarik dan komoditas, salah satunya adalah belanja busana. Belanja busana sering dikembangkan secara serius di sebuah destinasi karena salah satu jenis aktivitas yang cukup digemari wisatawan. Selain itu, jumlah pengeluaran (expenditure) tergolong tinggi untuk kegiatan ini, sehingga layak dipertimbangkan sebagai salah satu daya tarik wisata (Inskeep, 1991) dan media dalam memperoleh keuntungan.

Kota Bandung memanfaatkan belanja busana sebagai salah satu andalan dalam promosi dan menarik wisata. Kota yang sempat mendapat julukan "Paris Van Java" itu sedang gencar mempromosikan belanja busana di factory outlet beberapa tahun terakhir.

Promosi yang dilakukan semakin membuahkan hasil, area konsentrasi factory outlet adalah jalan Dago, RE Martadinata, dan jalan Setiabudhi. Konstantia dan Kuncoro (2010) mencatat bahwa sekitar $20 \%$ dari to- tal keseluruhan wisatawan yang datang ke Kota Bandung pada tahun 2008 terpusat di jalan Dago. Berarti dapat diperkirakan sekitar 15.000 wisatawan mancanegara dan 270.000 wisatawan domestik mengunjungi salah satu area konsentrasi factory outlet tersebut pada tahun 2008.

Tabel 1.

Jumlah Wisatawan dan Factory Outlet di Kota Bandung

\begin{tabular}{|c|c|r|c|c|}
\hline Tahun & $\begin{array}{c}\text { Wisatawan } \\
\text { Mancanegara }\end{array}$ & $\begin{array}{c}\text { Wisatawan } \\
\text { Domestik }\end{array}$ & Total & $\begin{array}{c}\text { Jumlah } \\
\text { Factory Outlet }\end{array}$ \\
\hline 2005 & 91.350 & 1.837 .500 & 1.928 .850 & 74 \\
\hline 2006 & 82.025 & 1.241 .416 & 1.323 .441 & 74 \\
\hline 2007 & 137.268 & 2.420 .105 & 2.557 .373 & 74 \\
\hline 2008 & 74.730 & 1.346 .729 & 1.421 .459 & 74 \\
\hline 2009 & 168.712 & 2.928 .157 & 3.096 .869 & 113 \\
\hline
\end{tabular}

Sumber: Disbudpar Kota Bandung, 2010.

Angka kunjungan wisatawan yang didapatkan di atas tergolong fantastis, mengingat banyaknya objek dan daya tarik wisata menarik lain yang dapat dikunjungi di Kota Bandung seperti, Saung Angklung Mang Udjo, Museum Konferensi Asia Afrika, Museum Geologi, Wisata Rohani Daarut 
Tauhid, Taman Hutan Raya Juanda, Bandung Indah Plaza, dan lain sebagainya.

Fenomena kunjungan wisatawan ke factory outlet disinyalir bukan hanya pengaruh dari promosi saja, tetapi juga merupakan akumulasi dari berbagai faktor termasuk motivasi wisatawan itu sendiri. Perlu disadari bahwa sebenarnya ketika wisatawan mengambil sebuah keputusan untuk berwisata, pasti telah melalui berbagai pertimbangan dan motivasi tertentu yang melandasi. Meskipun dalam kenyataannya hal tersebut sangat bersifat kompleks dan jarang diutarakan (implisit). Dann (1977) dalam Ross (1998) kemudian membagi motivasi untuk berwisata tersebut menjadi dua faktor, yakni faktor pendorong dan penarik. Faktor pendorong adalah motivasi spesifik wisatwan yang umumnya bersifat sosial-psikologis (internal), sedangkan faktor penarik merupakan atribut spesifik destinasi (eksternal).

Sebelum wisatawan memutuskan untuk melakukan kegiatan wisata belanja pasti ada faktor pendorong dan penarik yang melandasi. Sehingga hal itu menggugah rasa keingintahuan penulis untuk melakukan analisis. Agar masalah yang diteliti tidak terlalu luas, maka tujuan penelitian diarahkan untuk menganalisis persepsi wisatawan domestik mengenai faktor pendorong dan penarik dalam melakukan wisata belanja. Selain itu, juga untuk melihat pengaruh persepsi wisatawan dan kontribusi masingmasing faktor terhadap frekuensi kunjungan ke factory outlet Kota Bandung setiap tahunnya.

Daerah yang dijadikan sebagai lokasi penelitain adalah ketiga area konsentrasi factory outlet di Kota Bandung, yakni jalan Dago, jalan LLRE. Martadinata, dan jalan Setiabudhi. Sedangkan berdasarkan metode yang digunakan, bentuk penelitian merupakan penelitian survai yang menggunakan data primer sebagai sumber data utamanya. Populasi yang disasar adalah wisatawan domestik yang berbelanja di ketiga area tersebut. Jumlah sampel sendiri ditentukan menggunakan rumus yang dikembangkan oleh Wibisono (2003) untuk populasi yang tidak diketahui. Hasilnya penulis menggunakan sekitar 97 orang responden dengan metode accidental sampling dalam pengambilan datanya. Alat analisis data yang digunakan antara lain, distribusi frekuensi, interpretasi skor skala likert, dan analisis regresi berganda. Dalam pelaksanaannya penulis menggunakan bantuan software SPSS versi.18 untuk mengolah data yang didapatkan.

\section{KONDISI KEPARIWISATAAN KOTA BANDUNG}

Fungsi salah satu Kota Bandung adalah sebagai kota pariwisata (Data monografi Kota Bandung Tahun 2006). Hal tersebut dipertimbangkan Pemerintah Daerah karena banyaknya variasi pilihan kawasan wisata yang dapat dikunjungi wisatawan diantaranya, objek dan daya tarik wisata (ODTW) alam, budaya, belanja, kuliner, dan minat khusus. Tetapi dalam kenyataannya, setiap ODTW memiliki segmen pasar masingmasing khususnya berdasarkan asal geografis (domestik atau manca negara). Bila diperhatikan kembali, wisatawan mancanegara yang berwisata ke Kota Bandung lebih menggemari destinasi yang bersifat tidak masal contohnya, ODTW budaya dan minat khusus. Di sisi lain wisatawan domestik cenderung memilih destinasi wisata konvensional seperti, ODTW belanja, kuliner, dan alam.

Seiring dengan banyaknya variasi ODTW di Kota Bandung, sarana akomodasipun senantiasa semakin meningkat. Menurut data terakhir yang didapatkan, tercatat 84 buah hotel berbintang dan 190 hotel melati tersebar di kota Bandung. (Disbudpar Kota Bandung, 2011). Berbagai pilihan sarana akomodasi, diharapkan mampu memenuhi kebutuhan dan keinginan wisatawan dari berbagai segmen pasar. Selain itu, juga mampu mengakomodir seluruh wisatawan pada saat akhir pekan dan terlebih pada waktu hari-hari libur nasional. 
Gambar 1.

Kunjungan Wisatawan Domestik dan Mancanegara ke Kota Bandung

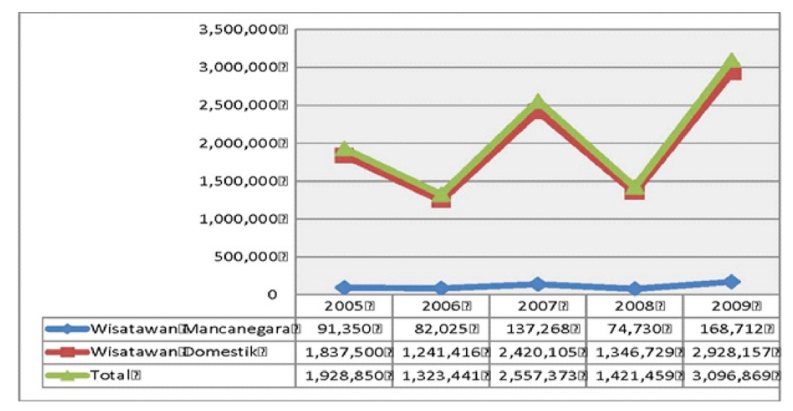

Sumber: Disbudpar Kota Bandung, 2010.

Jumlah kunjungan wisatawan ke Kota Bandung cenderung mengalami fluktuasi naik turun setiap tahunnya (gambar 1). Kondisi tersebut menimbulkan berbagai spekulasi Pemerintah Daerah dan stakeholder terkait untuk dapat menstabilkan jumlah kunjungan tersebut. Salah satu upaya yang dilakukan adalah dengan menambah penerbangan yang menghubungkan Kota Bandung dengan berbagai kota, seperti BandungPalembang dan Bandung - Pekanbaru. Selain itu, rute penerbangan ke luar negeri mulai dikembangkan, seperti Bandung- Kuala Lumpur dan Bandung - Penang.

Jumlah factory outlet menurut Dinas Koperasi UKM dan Perindustrian Perdagangan Kota Bandung pada tahun 2009, terdapat 113 buah yang tersebar di berbagai penjuru kota. Jumlah itu masih berpeluang besar untuk bertambah, mengingat kondisi yang masih menunjukan tanda-tanda positif. Perlu diketahui bahwa toko ritel tersebut mampu berkembang karena tidak hanya menjaring pembeli yang berasal dari Kota Bandung saja, melainkan juga dari luar kota seperti, Jakarta, Bogor, Depok, Bekasi, dan lain sebagainya.

\section{PROFIL WISATAWAN}

\section{Profil Demografi}

Beberapa tahun terakhir kontribusi yang dirasa sangat positif bagi perkembangan pariwisata di Kota Bandung berasal dari Dinas Pekerjaan Umum. Bentuknya berupa pembangunan infrastruktur jalan tol yang menghubungkan Cikampek, Purwakarta, dan Padalarang (Cipularang). Walaupun awalnya berfungsi untuk memudahkan aksesibilitas dari Ibukota menuju Bandung tetapi berdampak signifikan bagi perkembangan industri pariwisata di kota ini. Hal itu terbukti dari dominasi wisatawan asal Jakarta dan sekitarnya yang mendominasi total kunjungan wisatawan ke factory outlet Kota Bandung (75\%).

Kebanyakan wisatawan yang berkunjung ke factory outlet adalah wanita berusia muda. Hal tersebut bisa dipahami mengingat sebagian besar dari mereka ingin berpenampilan menarik, dan salah satu caranya dapat digambarkan melalui cara berbusana. Oleh karena itu wanita lebih mendominasi jenis wisata ini dibandingkan dengan pria.

\section{Profil Ekonomi}

Tingkat pencapaian pendidikan wisatawan yang datang ke factory outlet Kota Bandung didominasi oleh S-1 atau setingkat sarjana (60\%). Pada tahap itu, wisatawan tergolong mempunyai pendidikan yang cukup tinggi. Bila diperhatikan kembali temuan tersebut disebabkan karena tingkat pendidikan mempunyai pengaruh terhadap sudut pandang wisatawan. Merek contohnya, seperti diketahui factory outlet dikenal karena menjual busana dengan berbagai merek terkenal dari luar negeri. Sedangkan merek terkenal merupakan variabel penting bagi konsumen dengan brand knowledge yang baik, karena dapat mempengaruhi perilaku dan pemilihan produk (Kahn dan Schmittlein, 1989). Dilain pihak brand knowledge sangat dipengaruhi oleh tingkat pendidikan wisatawan. Hal itu karena umumnya semakin baik pendidikan yang dicapai seseorang, semakin baik pula wawasan mengenai merek terkenal.

Dari jenis pekerjaan, umumnya wisatawan adalah pekerja tetap dengan penghasilan antara Rp 2.500.000 s/d Rp 5.000 .000 (>60\%). Temuan tersebut sangat wajar, seperti diketahui barang yang dijual di factory outlet mempunyai harga yang tidak murah. Selain 
itu, perjalanan menuju Kota Bandung pun memerlukan biaya yang tidak sedikit, apalagi jika memperhitung kan biaya makan, minum, sarana akomodasi, dan lain sebagainya. Kondisi itu secara tidak langsung menuntut materi yang cukup, sedangkan kalangan pekerja tetap dari segi finansial tergolong tercukupi dan relatif stabil. Oleh karena itu, wisatawan dengan jenis pekerjaan tersebut pada dasarnya mendukung dan berpotensi untuk berbelanja di factory outlet Kota Bandung.

\section{Profil Psikografi}

Lebih dari $50 \%$ wisatawan yang disurvai menjadikan kegiatan wisata belanja ke factory outlet sebagai tujuan utama melakukan perjalanan ke Kota Bandung. Hal itu bisa dimengerti, karena pada dasarnya factory outlet menawarkan berbagai kelebihan dalam hal berbusana. Dari sisi produk misalnya, banyaknya variasi produk yang dijual, model busana yang beragam, merek terkenal dari luar negeri, dan harga jual yang lebih murah membuat wisatawan termotivasi untuk berkunjung.

Terlepas dari hal di atas, sebagian besar wisatawan mengunjungi factory outlet antara 1 hingga 6 kali dalam setahun, dengan rerata waktu belanja 1 sampai 4 jam. Kebanyakan wisatawan sendiri bermalam antara 1 sampai 2 hari di hotel berbintang, baik bersama teman maupun keluarga. Berbagai temuan tersebut mengindikasikan bahwa wisatawan yang berbelanja ke factory outlet Kota Bandung tergolong sebagai wisatawan psikosentris. Menurut Plog (1974) dalam Ritchie \& Goeldner (1994), ciri wisatawan jenis itu ialah mengunjungi destinasi secara berulang-ulang dan seringkali menuntut fasilitas yang standar. Sementara itu, Kota Bandung memiliki sarana dan prasarana yang cukup memadai, baik sarana akomodasi, transportasi, restoran, jaringan jalan, dan lain sebagainya.

Dari segi pengeluaran, pembeli yang digolongkan sebagai actives shopper dan price shopper itu juga biasanya menghabiskan uang dengan jumlah cukup besar dalam sekali kunjungan, yakni berkisar antara Rp 250.000 sampai Rp 1.000.000. Sebenarnya ada beberapa faktor yang mempengaruhi fenomena tersebut. Pertama, ketika barang dengan model tertentu habis terjual, kecil kemungkinan model yang sama akan dijumpai kembali di lain kesempatan. Hal tersebut membuat wisatawan yang datang khususnya pecinta belanja serta merta membeli barang yang cocok pada saat itu juga. Kedua, harga yang ditawarkan cenderung lebih murah dibandingkan daerah asal wisatawan. Ketiga, tidak setiap waktu wisatawan dapat membeli busana di factory outlet Kota Bandung karena jarak yang relatif jauh dari tempat tinggalnya. Alasan kedua dan ketiga itu ternyata mampu memotivasi mereka untuk memanfaatkan kesempatan belanja yang dilakukan dengan sebaik-baiknya, salah satunya dilakukan dengan membeli barang dalam jumlah cukup banyak.

\section{PERSEPSI WISATAWAN MENGENAI FAKTOR PENDORONG DAN PENARIK}

\section{Persepsi Wisatawan Mengenai} Faktor Pendorong

Berdasarkan hasil survai yang dilakukan di factory outlet Kota Bandung, hampir semua indikator faktor pendorong yang dijadikan alat ukur dipersepsikan benar atau mempengaruhi. Kecuali indikator ingin menunjukan prestise yang dinilai cukup benar oleh wisatawan. Temuan tersebut lebih lengkapnya dapat dilihat pada tabel 2 di bawah ini:

Tabel 2.

Skor dan Interpretasi Faktor Pendorong Statistics

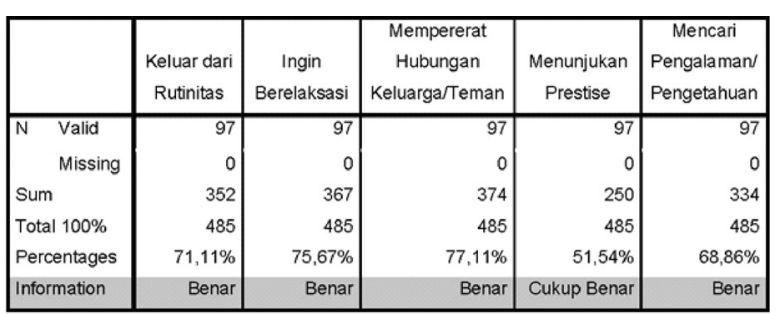

Sumber: Diolah dari data primer penelitian, 2011. 
a. Keluar dari Rutinitas

Bagi wisatawan asal Jakarta dan sekitarnya yang mendominasi kunjungan ke factory outlet Kota Bandung, persetujuan mengenai motif keluar dari rutinitas ini sangat bisa dipahami. Haruslah disadari bahwa pola kehidupan masyarakat di kota-kota besar sangatlah padat akan aktifitas dan rutinitas sehari-hari. Hampir sepanjang minggu mereka bekerja dari pagi hingga malam, mengalami kemacetan lalu lintas, menghirup udara yang tercemar karena polusi, serta bertemu dengan keramaian di berbagai tempat yang dilalui. Rutinitas tersebut mengakibatkan sebagian besar dari mereka merasa jenuh dan bosan, sehingga sesekali waktu membutuhkan aktifitas yang berbeda. Ternyata berwisata belanja ke factory outlet Kota Bandung dapat dijadikan sebagai salah satu alternatif kegiatan di waktu senggang.

b. Ingin Berelaksasi

Relaksasi dapat diartikan sebagai suatu kondisi mengistirahat kan fisik atau mental yang dilakukan seseorang. Berkenaan dengan berwisata belanja ke factory outlet di Bandung, wisatawan cenderung bertujuan untuk melakukan relaksasi mental. Seperti diketahui bahwa berbelanja mampu memberikan perasaan enjoy dan menyenangkan ketika dilakukan, sehingga mampu melupakan beban atau kejenuhan yang dirasakan walaupun untuk sejenak. Di sisi lain kegiatan berwisata belanja di factory outlet Kota Bandung tidak memungkinkan untuk tujuan relaksasi fisik dikarenakan berbagai hal. Pertama, perjalanan pulang pergi wisatawan dengan jarak relatif jauh, cenderung membuat kondisi tubuh mengalami kelelahan fisik. Kedua, lokasi factory outlet yang sebagian besar bersebrangan atau bersebelahan, "memaksa" wisatawan untuk mau berjalan kaki. Ketiga, banyaknya jumlah factory outlet membuka peluang wisatawan untuk lebih banyak beraktivitas dan memanfaatkan kesempatan sebaikbaiknya dibanding hanya berdiam diri.

c. Mempererat Hubungan dengan

Keluarga atau Teman.

Berdasarkan temuan yang didapatkan penulis dari wisatawan di factory outlet Kota Bandung, faktor pendorong yang paling dominan adalah mempererat hubungan dengan keluarga atau teman seperjalanan. Persetujuan tersebut bisa dipahami, karena ketika berwisata belanja wisatawan selalu berinteraksi satu sama lain untuk lebih mengakrabkan diri. Baik dari mulai kegiatan awal berupa pemutusan lokasi belanja, berkomunikasi dalam perjalanan di kendaraan, sampai bertukar pendapat mengenai produk yang akan dibeli. Banyaknya rentang waktu dari awal hingga akhir juga membuka peluang untuk membicarakan hal-hal di luar pekerjaan maupun persoalan yang bersifat formal lainnya. Apalagi jika kegiatan wisata dilakukan dengan tujuan menemui sahabat $^{1}$ atau keluarga di Kota Bandung, tentunya akan lebih mempererat hubungan karena rentang waktu bersama yang lebih panjang.

\section{d. Menunjukan Prestise}

Hampir Kebanyakan wisatawan berpendapat bahwa berwisata belanja ke factory outlet di Kota Bandung cukup menunjukan prestise seseorang. Walaupun faktor tersebut dipersepsikan paling rendah dibanding faktor pendorong lainnya. Ada beberapa alasan mengapa berbelanja di factory outlet dapat menunjukan prestise antara lain, Kota Bandung memiliki citra yang baik dalam hal belanja busana, tempat perbelanjaan memiliki fasilitas yang 
memadai, busana yang dijual mengikuti perkembangan tren, dan memiliki produk dari berbagai merek terkenal. Sementara itu rendahnya persepsi wisatawan dalam menilai motif ini diduga karena produk yang dijual memiliki kualitas kedua (barang sisa ekspor) dengan harga yang lebih murah dibanding pasaran pada umumnya. Kondisi tersebut menyebabkan wisatawan yang berasal dari kalangan tertentu (elite) akan sedikit malu untuk mengakui bahwa busana yang digunakan dibeli di factory outlet Kota Bandung.

\section{e. Mencari Pengalaman}

Menemukan pengalaman dan pengetahuan baru dalam bidang wisata, faktor pendorong dengan motif ini adalah bentuk keinginan wisatawan untuk mencari dan memperluas wawasan baru melalui kunjungan ke sebuah destinasi wisata. Sejalan dengan itu, persetujuan wisatawan yang membenarkan berbelanja ke factory outlet Kota Bandung mampu memberikan pengalaman atau pengetahuan baru sangat bisa dimengerti. Seperti diketahui, Kota Bandung merupakan salah satu daerah yang sering menjadi trendsetter fashion di tanah air. Masyarakatnya yang kaya kreatifitas selalu mengembangkan ide-ide baru dalam hal berbusana seperti, berani tampil beda, modis, elegan, unik, dan lain sebagainya. Kondisi tersebut menyebabkan wisatawan dengan mudah dapat langsung melihat dan mempelajari gaya busana yang sedang menjadi tren mode terkini. Akumulasi pengetahuan dan pengalaman berbusana yang didapatkan ketika melakukan kegiatan berbelanja sendiri dapat diaplikasikan wisatawan dalam berpenampilan sehari-hari di daerah asal.

\section{Persepsi Wisatawan Mengenai Faktor Penarik}

Persepsi Wisatawan Mengenai Faktor Penarik tidak jauh berbeda dengan hasil yang didapatkan penulis mengenai faktor pendorong, hampir semua indikator variabel faktor penarik pun dipersepsikan benar oleh wisatawan, kecuali indikator harga barang murah yang dinilai cukup benar. Temuan tersebut lebih jelasnya dapat dilihat pada tabel 3 di bawah ini:

Tabel 3.

Skor dan Interpretasi Faktor Penarik Statistics

\begin{tabular}{|c|c|c|c|c|c|c|}
\hline & Murah & Merek & Kualitas & Model & Citra & Produk \\
\hline Valid & 97 & 97 & 97 & 97 & 97 & 97 \\
\hline Missing & 0 & 0 & 0 & 0 & 0 & 0 \\
\hline Sum & 281 & 320 & 350 & 365 & 375 & 376 \\
\hline Total $100 \%$ & 485 & 485 & 485 & 485 & 485 & 485 \\
\hline Percentage & $57,93 \%$ & $65,97 \%$ & $77,11 \%$ & $72,16 \%$ & $77,31 \%$ & $77,52 \%$ \\
\hline Information & Cukup Benar & Benar & Benar & Benar & Benar & Benar \\
\hline
\end{tabular}

Sumber: Diolah dari data primer penelitian, 2011.

a. Harga Barang Murah

Harga murah merupakan salah satu faktor penarik yang luar biasa bagi wisatawan untuk berkunjung. Bahkan sebagian dari mereka, rela melakukan perjalanan jauh demi mendapatkan penawaran harga murah (Timothy, 2005). Terbukti dari temuan penulis di factory outlet Kota Bandung, harga jual barang yang murah dinilai wisatawan cukup menarik mereka untuk berbelanja di lokasi factory outlet. Meskipun dalam kenyataannya, faktor ini merupakan yang terendah dibanding faktor penarik lainnya. Haruslah disadari sebelumnya bahwa pengertian murah di factory outlet adalah lebih rendah dibanding harga yang berlaku di pasaran pada umumnya, sehingga masih bersifat relatif. Jadi bagi sebagian orang yang memiliki kemampuan ekonomi tertentu, berbelanja di factory outlet masih tergolong mahal dan eksklusif. 
b. Merek Terkenal

Dalam konteks psikologi pariwisata merek terkenal merupakan faktor penarik yang sangat kuat bagi wisatawan untuk mengunjungi sebuah destinasi. Hal itu dikarenakan sebuah merek mampu mempengaruhi perilaku dan pemilihan produk seseorang (Kahn dan Schmittlein, 1989). Pendapat itu terbukti dari persetujuan wisatawan yang membenarkan bahwa salah satu faktor penarik untuk berbelanja di factory outlet Kota Bandung adalah merek terkenal. Factory outlet mampu menyediakan berbagai macam merek terkenal karena tidak hanya menjual produk sisa ekspor buatan Indonesia saja, tetapi juga mengimpor dari Singapura, Malaysia, Kamboja, Filipina, Srilanka, China, dan bahkan dari Afrika Selatan.

c. Kualitas Barang yang Baik

Barang yang dijual di factory outlet pada umumnya memiliki kualitas cukup baik, karena pada dasarnya barang yang dijual di lokasi ini memiliki tingkat kualitas yang sama dengan barang dikirim ke luar negeri. Walaupun sebagian orang menyebut barang tersebut dengan istilah "sisa ekspor" atau barang "reject", tetapi sebenarnya factory outlet hanya menjual barang yang memiliki grade A atau yang terbaik setelah melalui proses penyortiran yang ketat. Hal di atas dipertegas dengan data yang didapatkan penulis dari hasil survai yang dilakukan. Sebagian besar wisatawan menyetujui bahwa barang yang dijual di factory outlet Kota Bandung mempunyai kualitas yang baik.

\section{d. Keragaman Model}

Berdasarkan data, keragaman model yang dijual di factory outlet mampu menjadi magnet dalam menarik kunjungan wisatawan. Ada beberapa alasan mengapa factory outlet dapat menyediakan barang dengan model yang beranekaragam. Pertama, perbedaan produsen atau distributor sebagian besar toko sangat memungkinkan produk yang dipasarkan memiliki model yang berlainan. Kedua, barang yang dijual senantiasa diupdate mengikuti perkembangan mode terkini. Hal tersebut dikarenakan produk dan model barang yang dijual sebenar nya merupakan pesanan dari pihak luar negeri (sisa ekspor). Ketiga, produk yang ditawarkan pada dasarnya terdiri dari berbagai merek, sehingga setiap produk memiliki model yang berbeda-beda. Keempat, banyaknya industri tekstil maupun perusahaan konveksi yang berada di sekitar Kota Bandung memudahkan pengusaha untuk bekerjasama dalam memproduksi busana dengan berbagai model yang diinginkan.

e. Citra Destinasi yang Baik

Citra destinasi wisata amatlah penting karena dapat mempengaruhi keputusan wisatawan. Hal itu disebabkan karena citra dapat memberikan kesan suatu destinasi akan menawarkan atraksi yang berbeda dibanding destinasi lain yang pernah dikunjungi (Pitana \& Gayatri, 2002). Sedangkan bagi wisatawan yang pernah berkunjung, citra yang terjaga baik dapat mempengaruhi mereka untuk melakukan kunjungan ulang (repeater).

Pendapat di atas terbukti dari hasil temuan di factory outlet Kota Bandung, salah satu faktor penarik wisatawan untuk berbelanja karena destinasi tersebut memiliki citra yang baik dan terjaga dalam hal belanja busana. Sebenarnya bila dikaji lebih jauh, persepsi wisatawan mengenai citra belanja yang baik di factory outlet itu dapat timbul karena berbagai faktor antara lain, lokasi perbelanjaan yang mudah dijangkau, jumlah toko yang banyak, desain interior dan eksterior toko yang menarik, fasilitas memadai, 
penataan mannequin yang tertata rapi, barang yang ditawarkan bervariasi, dan berbagai kelebihan lain yang ditawarkan factory outlet di Kota Bandung.

\section{f. Produk Bervariasi}

Berdasarkan temuan, produk bervariasi dinilai wisatawan sebagai salah satu faktor penarik untuk berbelanja di factory outlet Kota Bandung. Hal tersebut sangat bisa dimengerti, mengingat beberapa keuntungan yang diperoleh wisatawan dari banyaknya variasi barang ditawarkan di sebuah factory outlet. Pertama, produk yang beragam dapat memberi banyak alternatif pilihan barang yang dapat dibeli wisatawan. Kedua, besar kemungkinan satu lokasi perbelanjaan mampu memenuhi berbagai kebutuhan busana yang diperlukan (one stop shopping). Ketiga, produk yang bervariasi di suatu lokasi dapat mengurangi kelelahan fisik dan mempersingkat waktu berbelanja wisatawan. Hal itu disebabkan mereka tidak perlu ke lokasi lain untuk memenuhi berbagai kebutuhan lain yang diperlukan.

\section{PENGARUH PERSEPSI WISATAWAN MENGENAI FAKTOR PENDORONG DAN PENARIK TERHADAP FREKUENSI KUNJUNGAN}

Melalui pengolahan data yang dilakukan penulis dengan bantuan software komputer SPSS versi.18, persamaan regresi berganda yang tercipta dalam penelitian ini dapat digambarkan sebagai berikut:

$$
\hat{Y}=-3,164(\mathrm{a})+0,797(\mathrm{X} 1)+0,855(\mathrm{X} 2)
$$

Nilai koefisien regresi faktor pendorong sebesar 0,797 dan faktor penarik sebesar 0,855 yang menunjukan tanda positif dan searah di atas menyatakan bahwa, apabila skor persepsi wisatawan mengenai faktor pendorong dan penarik mengalami peningkatan, maka frekuensi kunjungan ke factory outlet Kota Bandung pun semakin meningkat. Sementara itu dari hasil pengolahan data juga dipastikan bahwa nilai Fhitung $(16,941)$ lebih besar dibandingkan Ftabel $(2,793)$, yang berarti bahwa kedua faktor tersebut berpengaruh signifikan terhadap frekuensi kunjungan wisatawan ke factory outlet Kota Bandung setiap tahunnya.

Temuan di atas bisa dipahami, mengingat kedua faktor tersebut sesungguhnya merupakan motivasi utama wisatawan untuk berwisata belanja. Dengan adanya adanya dorongan dari segi internal, wisatawan memiliki keinginan untuk berbelanja busana, tetapi masih belum jelas destinasi mana yang dituju. Ternyata dengan banyaknya berbagai faktor penarik yang dimiliki factory outlet di Kota Bandung, menyebabkan sebagian wisatawan dengan segmentasi tertentu memutuskan untuk berbelanja busana di lokasi tersebut.

\section{KONTRIBUSI FAKTOR PENDORONG DAN PENARIK TERHADAP FREKUENSI KUNJUNGAN}

Melalui hasil penghitungan yang dilakukan diketahui bahwa masing masing variabel memberikan kontribusi terhadap frekuensi kunjungan wisatawan setiap tahunnya sebesar $18 \%$ untuk faktor pendorong, dan $19 \%$ untuk faktor penarik. Angka itu tergolong rendah, tetapi bila kedua faktor digabungkan akan menambah nilai kontribusi menjadi $26,5 \%$. Sementara sisanya sebesar 73,5\%, dijelaskan oleh indikator atau variabel lain yang tidak diteliti dalam penelitian ini.

Rendahnya kontribusi faktor pendorong dan penarik terhadap frekuensi belanja wisatawan di atas disinyalir karena banyaknya motif lain yang tidak dijadikan sebagai indikator dalam penelitian ini. Dari faktor pendorong motif lain yang dimaksud seperti, wisatawan ingin menambah koleksi busana pribadi, mencari produk yang memiliki merek atau model spesifik tertentu, menemukan gaya busana yang cocok bagi dirinya (own style), membahagiakan keluarga atau teman dengan membelikan busana yang dijual di factory outlet, dan lain sebagainya. 
Sementara itu, dari faktor penarik motif lain yang tidak dijadikan sebagai indikator diantaranya, pelayanan baik yang diberikan factory outlet, tempat belanja tergolong nyaman karena berbagai fasilitas yang disediakan, desain bangunan factory outlet yang unik dan menarik, kemudahan aksesibilitas untuk menjangkau lokasi, fasilitas pendukung yang berada di sekitar tempat perbelanjaan, dan tertarik karena banyaknya destinasi wisata lain yang dapat dinikmati di Kota Bandung.

\section{KESIMPULAN DAN SARAN}

\section{Kesimpulan}

Berdasarkan hasil temuan di lapangan serta hasil pengolahan data yang dilakukan, dapat ditarik beberapa kesimpulan antara lain:

a. Wisatawan yang berbelanja ke factory outlet Kota Bandung sebagian besar berasal dari Kota Jakarta dan sekitarnya, dengan didominasi wanita pada usia muda serta terpelajar. Mereka umumnya adalah pekerja tetap dari golongan berpenghasilan menengah, dan menjadikan kegiatan berbelanja busana sebagai tujuan utamanya untuk melakukan perjalanan ke Kota Bandung.Kebanyakan wisatawan jenis psikosentris ini menginap antara 1 sampai 2 hari di hotel berbintang, baik bersama teman maupun keluarga. Kunjungan ke factory outlet sendiri pun seringkali dilakukan 1 hingga 6 kali dalam setahun, dengan waktu belanja antara 1 sampai 4 jam. Selain itu, pembeli yang digolongkan sebagai actives shopper dan price shopper itu juga biasanya menghabiskan uang dengan jumlah cukup besar dalam sekali kunjungan, berkisar antara Rp 250.000 sampai Rp 1.000.000.

b. Faktor pendorong yang paling mempengaruhi wisatawan untuk berbelanja ke factory outlet Kota Bandung secara berurutan adalah, mempererat hubungan kekerabatan baik dengan teman maupun keluarga, ingin berelaksasi, keluar dari rutinitas seharihari, mencari pengalaman atau pengetahuan baru, dan menunjukan prestise. Sedangkan faktor penarik dimulai dari yang paling mempengaruhi wisatawan diantaranya, produk yang bervariasi, citra destinasi yang dianggap bagus, kualitas barang dagangan yang dianggap baik, keragaman model yang ditawarkan, merekmerek yang terkenal, dan harga barang yang dinilai murah.

c. Berdasarkan persamaan analisis regresi berganda yang didapatkan, secara keseluruhan faktor pendorong dan penarik memberikan pengaruh positif terhadap frekuensi kunjungan wisatawan setiap tahunnya. Selain itu, uji hipotesis juga membuktikan bahwa nilai Fhitung lebih besar dari Ftabel, yang memiliki arti bahwa secara berganda ada pengaruh yang signifikan dari faktor pendorong dan penarik terhadap frekuensi kunjungan wisatawan setiap tahunnya. Oleh karena itu dalam penelitian ini hipotesis awal $(\mathrm{Ha})$ yang diajukan penulis dapat diterima.

d. Melalui perhitungan koefisien determinasi $\left(\mathrm{R}^{2}\right)$ diperoleh hasil bahwa, kontribusi faktor pendorong terhadap frekuensi kunjungan wisatawan setiap tahunnya adalah sebesar $18 \%$, sedangkan faktor penarik sebesar 19\%. Hal itu sebenarnya tergolong cukup kecil, tetapi bila kedua faktor tersebut digabungkan akan memberikan nilai kontribusi yang lebih besar yakni $26,5 \%$, sementara sisanya sebesar $73,5 \%$ dijelaskan oleh variabel atau indikator lain yang tidak diteliti dalam penelitian ini.

\section{Saran}

Berdasarkan temuan hasil survey dan analisis data, penulis memberikan saran:

a. Bagi pengusaha factory outlet di diharapkan dapat lebih meningkatkan kualitas pelayanan dan melengkapi jenis 
barang yang dijual, baik dari variasi produk maupun model busana. Hal itu bertujuan agar wisatawan semakin tertarik untuk berbelanja, sedangkan bagi wisatawan yang sering berkunjung (repeater) tidak pernah bosan untuk berbelanja kembali.

b. Bagi Dinas Pariwisata Kota Bandung agar dapat lebih mempromosikan kegiatan wisata belanja di factory outlet ke daerah-daerah lain yang sekiranya potensial selain Kota Jakarta dan sekitarnya. Kegiatan tersebut menjadi penting karena suatu saat wisatawan asal daerah tersebut akan mengalami stagnasi dan bahkan penurunan dari segi kunjungan. Kondisi itu disebabkan karena perasaan bosan yang mungkin timbul akibat kegiatan belanja yang dilakukan berulang-ulang. Selain itu, bila kunjungan wisatawan bertambah akan memberikan keuntungan bagi Pemerintah Daerah dan stakeholder yang terkait diantaranya, pemasukan pajak yang meningkat, bergeraknya roda perekonomian masyarakat, pengenalan kebudayaan, dan lain sebagainya.

c. Bagi peneliti sejenis lain yang tertarik, melalui hasil perhitungan koefisien determinasi mengenai indikator faktor pendorong dan penarik dalam penelitian ini hanya mampu menjelaskan sekitar 26,5\% dari total nilai keseluruhan kontribusi sebesar $100 \%$. Hal tersebut mengindikasikan bahwa masih banyak variabel atau indikator lain yang bisa digali dan ditambahkan untuk memprediksi frekuensi kunjungan wisatawan yang berbelanja ke factory outlet Kota Bandung setiap tahunnya. Selain itu, pembukaan wahana baru seperti Trans Studio dan juga pembukaan jalur penerbangan yang memudahkan aksesibilitas di Bandara Husein Sastranegara akhir-akhir ini, dapat membuka kesempatan bagi peneliti lain untuk melihat sejauh mana dampak yang diberikan bagi perkembangan $f a c-$ tory outlet di Kota Bandung.

\section{DAFTAR PUSTAKA}

Akdon. \& Hadi, Sahlan. (2005). Aplikasi Statistika dan Metodologi Penelitian untuk Administrasi dan Manajemen. Bandung: Dewa Ruchi.

Badan Perencanaan Pengembangan Daerah Provinsi Jawa Barat. (2009). Profil Daerah Provinsi Jawa Barat Tahun 2009. Bandung: Tidak diterbitkan.

Badan Pusat Statistik Kota Bandung. (2010). Kota Bandung Dalam Angka. Bandung: Tidak diterbitkan.

Inskeep, Edward. (1991). Tourism Planning An Integrated an Suistainable Developement Approach. New York: Van Nostrand Reinhold.

Kahn, Barbara E. \& Schmittlein, D.C. (1989). Shopping Trip Behavior: An Empirical Investigation. Marketing Letters, 1 (1): 55-69.

Pitana, I.G. \& Gayatri. P.G. (2005). Sosiologi Pariwisata. Yogyakarta: Penerbit Andi.

Ritchie, Brent.J.R. \& Goeldner, Charles R (1994). Travel, Tourism and Hospitality Research, A Handbook for Manager and Researcher. New York: Jon Wiley and Son, Inc.

Ross, G. F. (1998). Psikologi Pariwisata. Toety Heraty Noerhadi, translator. Jakarta: Yayasan Obor Indonesia.

Timothy, D.J. (2005). Shopping Tourism, Retailing, and Leisure. Great Britain: Cromwell Press. 
Sumber-sumber lain:

Data monografi Kota Bandung (2006)

http://www.bandung.go.id (diakses pada tanggal 20 Januari 2011) http://www.karir-up.com/2008/06/perrytristianto/ (diunduh pada tanggal 25 Januari 2011)

http://www.pikiran-rakyat.com/node/ 144240 (diakses pada tanggal 11 Juni 2011). 